医学図畫館 $22(1): 49 \sim 53,1975$

\title{
画像通信システムの展望について \\ Prospects of visual telecommunication systems
}

\author{
電電公社関東電気通信局情報処理室 \\ 伊藤 正 幸*
}

\section{1. はじめに}

編集者から最初依頼を受忛たのは「模写電送」につい て書いて欲しいといらことであった。しかし現在の電気 通信は, 電詀, 雪信といった通信方式汶して「模写電 送」といら分野があるのではなくて模写電送をも含めた 「画像通信」といら広い分野で発展しょらとしている。 また現在の電気通信技術の組合せは複䧴になってきた。 特に昭和 47 年 11 月の公竞電気通信法の改正により, 電 話回線が音声通信以外飞も利用できるよう飞開放された のでファクシミリやデータ伝送にも使われるようになっ たっいずれはテレビ電話も実用化されるであるら。そうし た意味からいま電電公社ではこれらの一切を含めた「総 合通信網」といら，特に画像通信が低コストで，しかも 良品質の伝送ができる新しい分野の開発仅り組んでい る。㶢机で怯画像通信とはどらいらものか, その中でる 代表的なファクシミリ（従来は模写電信, 写真電信と呼 ばれてきたりとついて，その利用は今後の情報社会にと ってどんなメリットがあるかなどとついて若干調べたこ とについて述べさせてもらいます。

\section{2. 画像通信の概要}

\section{1 画像通信とは何か}

情報が「発信者」から「送信機」「云送路」「受信機」 を通って「受信者」(相手)に伝わる一般的な電気通信シ

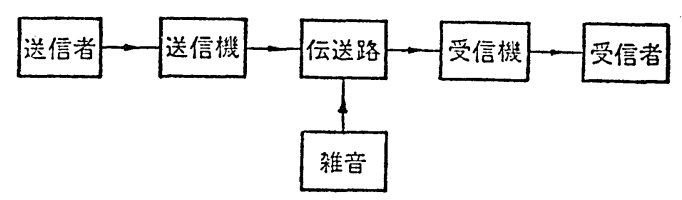

図1

* Masayuki ITO : Information Control Room, Nippon Telegraph and Telephone Corp.
ステムは図1 亿示すと抢りである。

画像通信システムでも, この基本的なパターンには変 りはない。その図式を図2に示す。

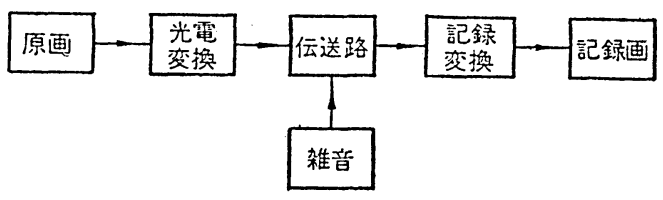

図 2

さらにこれにコンピュータを使った情報処理システム が組み达まれると図３のようになる。

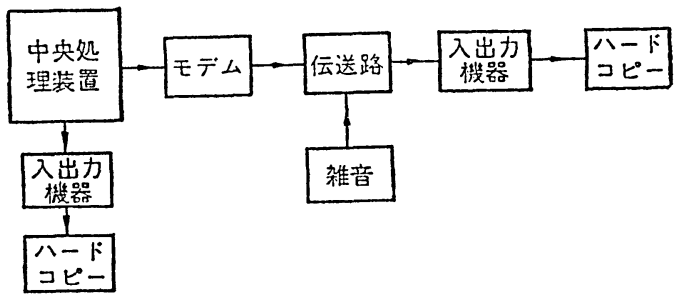

図 3

電話が音声情報を伝える のに対して, 画像通信シス テムでは「特定の場所から 特定の場所への，あるいは 特定の人から特定の人への 視觉情報(画像)の伝達をす るシステム」であるといえ る。特にファクシミリのよ らな記録画が得られるもの を画像記録通信と呼んでい る。電気信号を受信側で受 けとってコピーを得るプロ セスを図示すると図 40 の

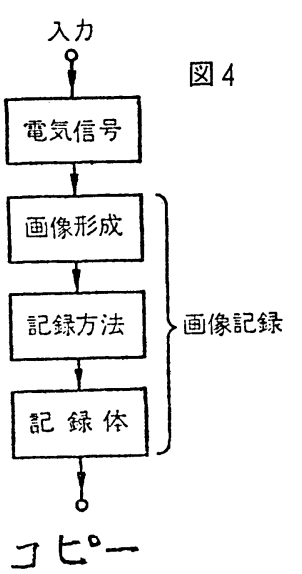


らになる。

では次にこれらの個々の点について概説する。

\section{2 入力情報}

画像通信における入力情報の効象となるもの, つまり 送信側で情報の収集対象となり得るものは，文字，記号， 図形, 写真, 絵画, 物品, 人物, 情景等視覚情報のすべ てにわたっている。もちろん，これらが全ての画像通信 システムで可能なのではない。以下にのべるいろいろな 制約条件や，最適方式の問題，コスト，需要の問題等実 用性によって実際にわれわれが使えるシステムや機種は 作られることになる。

\section{3 電気信号, 伝送路}

電気信号の伝送の問題は専門的で複雑なので省略する ことにする。伝送路としては各種有線，無線の方式があ り，一般ユーザとして電電公社の回線を利用する場合に は伝送路の方式がなんであるかについて注意する必要は ないと思われる。

\section{4 面像形成}

電気信号からそれに対応する画像を形成させる方法を 「画像形成」という，大別与ると走査形，画素形，文字 形, ベクトル形の方法がある。

\section{4.1 走查形}

ファクシミリ，テレビで代表される走査(Scanning)により画像を形成する方法である。

2. 4. 2 画素形

多数の画素 (picture element)の集合として画像を 形成する方法で，多数の点の集まりで文字や図形を 表す。電光ニュースは函素形の1例である。

2. 4. 3 文字形

従来の機械式の印刷電信機, タイプライターなど で電気信号を受けて，それに対応する所定の文字を 選んで動作させて記録誌にプリントさせる方法。

2. 4. 4 ベクトル形

CRTやプロッタに多く用いられる方法である。 文字や図访を形成するのに線の合成によって表示寸 るもので，一筆書きの要領で形成されるので，スト ローク形とも呼ばれる。

\section{5 記録方法}

形成された画像をハードコピーにする方法は記録体 に何を用いるか, その組合せによって変ってくる。次 にその代表的なるのを概説する。

\section{5. 1 電磁式}

電磁式は主として文字形の画像形成に用いられて
いる。(2.4.3 参照)從来の印刷電信機, ラインプリ ンタなどに広く用いられている方法である。印字の エネルギー源にマグネットを多く用い，印字部分を 動作させて機械的に吒いて記録を得る方法である。

2. 5.2 静電式

静電記録は，高圧で絶縁記録紙に静電荷を与え, 微紛末で現像して記録を得る方法である。プリンタ， ファクシミリに広く使われて括り, 画像形成は画素 形, 走查形, 文字形いずれでも用いられる。

2. 5.3 電告式

情報に応じて電圧を加えて記録する方法である。 放電破壞式が広く用いられている。記録針に電圧を 印加し，放電により絶縁層を破壞し黑色の層を出し 記録を作るもので，主として走查形で用いられる。 謄写ファックスはこの応用例である。

2. 5.4 電流式

情報に応じ電流を流し発色させる方法である。記 録電極と電解記録紙とを接触さ梿電流を流し電極が 記録紙に含浸させた電解質と化学反応して発色する むのと, 電解澌が分解してその生成物が発色するも のとがある。

\section{5. 5 熱記録}

情報によって電極に加熱するとこれに対向した部 分の記録紙が発色する。多くは画素形で，比較的遅 い電子プリンタに用いられている。

2. 5.6 磁気記録

磁気シートに磁気的に画像を形成し，これを磁性 紛で現像し，この像を普通紙に転写して用いる方法 である。磁気シートは消極して繰返し用いる。

2. 5. 7 インクジェット記録

細いノズルから着色した液体を噴射し，文字や図 形を描く方法である。プリンタ、ファクシミリ、レ コーダなどに用いられている。画像形成は画素形で ある。

2. 5.8 光記録

記録手段に光を用いるものはすべて光記録といえ る。情報により画像を形成させて発光させ，この像 を感光性記録体に受けてハードコピーするものであ る。画像形成は画素形, 走查形, 文字形, ベクトル 形などすべての形が用いられる。電子ビームを制御 してディスプレイに出し，記録するものがかなり多 い。画像を光学系を通して感光性記録体に当てる形 它多い。 


\section{6 記録体}

記録体には，情報に応じて直接記録するる非感光性の 記録体之, 感光性記録体之が㐫る。朗録体も画像形成 の方法や記録方法との組合边飞拈いて最適のもの方採 られる。

\section{6.1 非感光性記録体}

非感光性記録体は通常記録紙と㖤ばれているもの である。カーボン紙, 静電記録紙, 放電破壊紙, 霄 解記録紙，感熱記録紙，感圧記録紙など各種のもの がある。これらは特咮記録紙と呼ばれ，わが国では 10 数社によって市販されている。

\section{6.2 感光性記録体}

感光性記録体は古くは銀塩写真が主であったが， 最近では電子写真, 有機感光材料などがある。

\section{7 画像品琱}

画像品質はファクシミリ等においては主として解像度 (分解度)によって支配される。解像度は線密度によって 支配され，電送速度之密接な関㭛がある。(線密度を高 くなると電送速度が遅くなるといら逆比の関係にある) 解像度は分解して認識できる極限の平行線の数を $1 \mathrm{~mm}$ 当りの本数(線密度)で示少のが普通である。ファクシミ
リなどでは白黑の平行線の $1 \mathrm{~mm}$ 当りの線をいう。

㲹録再現の文字の大きさは，いくつかの調査に上れば, 新的活字程度の精密さ(7.5 9 ポイント)が要求されて いる。このための走查線密度は $7 \sim 8$ 本 $/ \mathrm{mm}$ が必要だ といわれる。しかし，現在熟用機を除く市販されている 送受信㳖用のフックシミリではこれだけの規格を充たす ものは少い。記録画に対少万要㘹注解像度の他, 中間調 再現, 色特性, カラー化なども今後要求さ机てくるもの と思われるが，新閆淑道など特殊なるの以外コスト面で バランスがとれないために今のところ需要は少い。

\section{3. 情報伝達からみた画像通信システム}

電話に抢行る音声情報の伝達の場合には，相手に情報 を伝達するのを目的として通常双方向会部方式でなさ礼 る。画像通信で注視覚情報それ自身は必らずしも他伀 光るこを目的としたものではなく，その情㘧を受取っ た人がその中から必要に応じて偭值判断して選択し，受 入れればよいものである。特に画像記録通信の場合は来 後での選択が可能である。また，相互通信形をとる場合 にも，ファクシミリ等では，通常電話のような双方向会 話形でなく，時差をおいて相互に通信がおこなわれる。

表 1 画像電送システムの形態

\begin{tabular}{|c|c|c|c|c|}
\hline \multicolumn{2}{|c|}{ 分 類 } & 话 伤 形 & システム槛成 & 邀 肞 例 \\
\hline \multirow{2}{*}{$\begin{array}{l}\text { 杖 } \\
\text { 互 } \\
\text { 近 } \\
\text { 信 } \\
\text { 非 }\end{array}$} & 拄通形 & 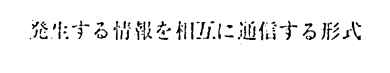 & $-\left[\begin{array}{l}\mathrm{S} \\
\mathrm{R}\end{array}\right.$ & 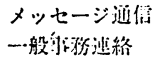 \\
\hline & 艾捘形 & 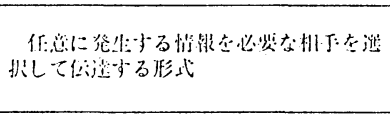 & 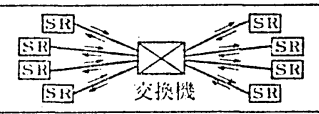 & 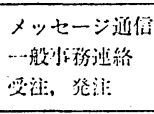 \\
\hline \multirow{5}{*}{$\begin{array}{c}- \\
y_{j} \\
\text { [iif } \\
\text { jifi } \\
\text { 㩁 } \\
\text { 形 }\end{array}$} & 炇恣形 & 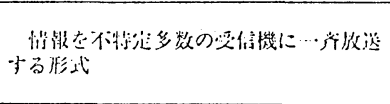 & 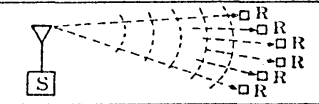 & 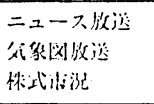 \\
\hline & 间翰形 & 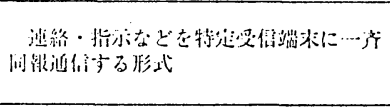 & 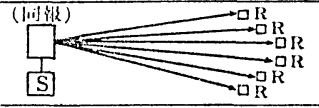 & 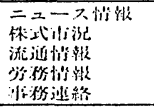 \\
\hline & 配.仙 形 & 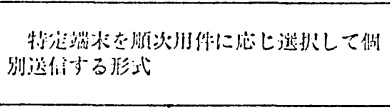 & S & 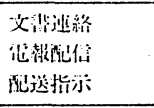 \\
\hline & 㖛佽形 & 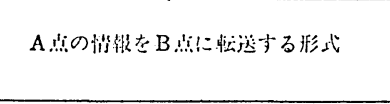 & $\rightarrow R$ & 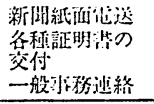 \\
\hline & 任住形 & 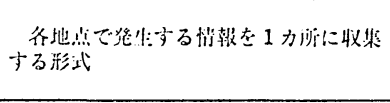 & 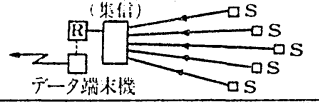 & 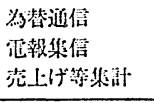 \\
\hline & 俋济形 & 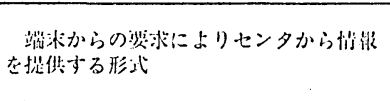 & 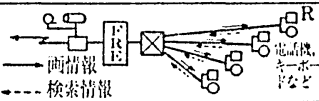 & 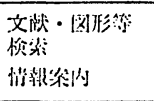 \\
\hline
\end{tabular}

(注)小林 p. 30 
これからの画像通信の形態としては集信形と配信形とを 組合せたシステムなど複合的なものや，コンピュータに よる画像情報処理機能を取り入れたより高度なシステム も出現するのではないかといわれている。それらの通信 形態を表 1 亿示す。

\section{4. 通信方式から見た画像通信システム}

画像通信の表示方式に以記録が残るハードュピー方式 と, 残らないソフトコピー方式とがある。通常前者は静 止画方式であり，後者は斯画方式である。最近ではビデ オ方式も開発されている。電話やテレビの発達した現在 に执いても，征便や，新閏の必要性が少しもらすれてい ないことを侾るとハードコピーは表示方式としては今 後の情報社会に打いても極めて重要であるといえる。電 気通信システムにおける画像通信の位圆を図示すると図 5 のようになる。

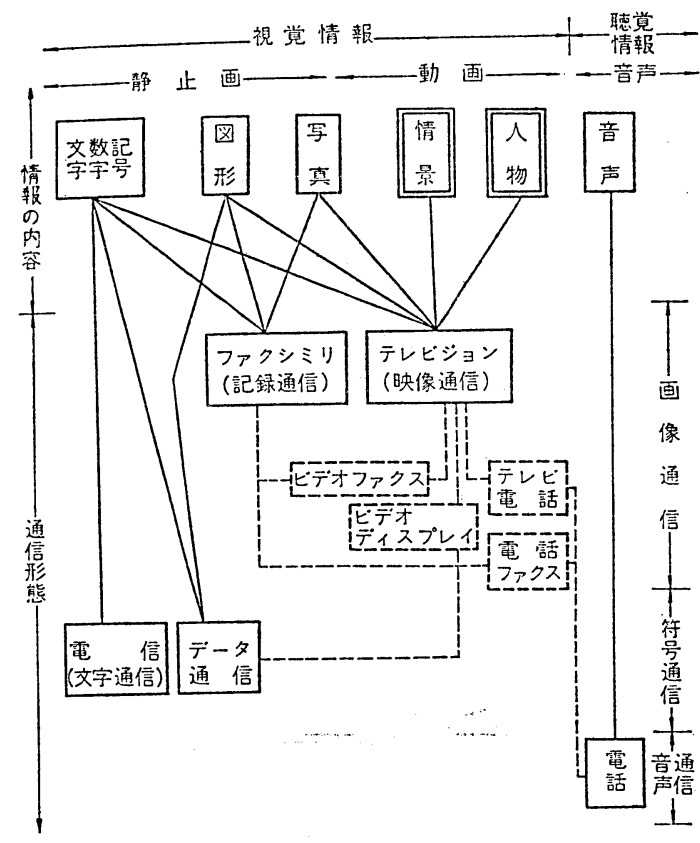

(注) 窪田 p.19による

\section{図 5 電気通信形態の分類}

\section{5. ファクシミリ利用の効用性}

画像通信の代表であるファクシミリ利用の効用性につ いてながめてみよう。

\section{1 ファクシミリの利用分野}

ファクシミリは, 原書画に忠実な状態で遠隔地との間
で記録を送受信できるという特徵をもっている。少し性 能の上い機械を選べば高精度の書画通信や，写真等の中 間調も再現し得る機能をもった通信方式である。

従来からこの利点を生かして、ファクシミリは(1)写真 電送, (2)気像観测図の電送, (3)指紋, サインの電送, (4) 新聞紙面電送, などの特殊な用途の画像通信に用いられ てきた。

最近では，(1)漢字まじりの文章でも送れる，(2)図面も 送れる，(3)取扱いが容易で操作寸るのに専用のオペレー タが必要でない，(4)通信内容が正確・確実に伝わる，な どの効用面が認められて, 事務の合理化や省力化の手段 として一般ビジネス分野での使用が活発化してきた。さ らに公衆電話網の開放後は端末機の開発も盛んで一層は なやかになってきている。今後ファクシミリ端末の一層 の経済化が進めば，将来には一般家庭での利用も十分考 えられるといわれている。

\section{2 他の記録通信システムとの比較}

ファクシミリと類似の記録手段として現在使われてい る通信方式としては，郵便，電報，加入電信，手書き電 送などがある。この他電話による筆記とかデイスプレイ からハードコピーをとる手段なども可能であるが ここ では直接通信系においてハードコピーを得られるものに 限定して比較された表 2 を提示するる。

(1)電話は便利で非常に普及しているので, 何時でも, 誰とでも，乙かも会話形式で話せるが，情報が正確に伝 わら等いことと、テープレコーダ等で記録すれば別だが 記録が残らないのに対してファクシミリは情報が正確に 伝わり，記録が残り，何時でも再利用が可能である。(2) 加入電信においては記録は残るが, 専門のオペレータが 必要だし, 一定の符号 (文字) のみしか送れないし, 漢字 まじりの文書を伝達するのには，カナまたはローマ字に ほ九字して専門のオペレータが打けんして送信し，これ を受信した側では，また漢字による文章として再生しな ければならない。こ机では, 当然情報の歪も予想しなけ ればならないし，時間出かか，専門のオペレータを必 要とするなど，直接費以外のロス必馬鹿にならない。画 像通信ではこれらのすべてを解決してくれる。公式命令 文書や，情報の一斉伝達をファクシミリを使って行って いるところも多い。

\section{3 電話網を使ったファクシミリ}

最近○○ファクスといったような商品名で一般加入電 話網で使用でさるファクシミリが約 20 種近く市肘され ている。現在, 原稿サイズはA 4 判を送るのが標準とな 
表 2 記録通信分野におけるファクシミリの評価

\begin{tabular}{|c|c|c|c|c|c|c|c|c|c|c|c|}
\hline 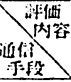 & 版 版 & 湖 & 分 少 性 & 就 & 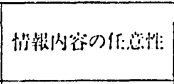 & ititi & $\begin{array}{l}\text { 䜣: 确 性: } \\
\text { (确 招 性) }\end{array}$ & 佂 & 経 济 栍: & 仳 & 锌 \\
\hline $\begin{array}{l}\text { ファク } \\
\text { シミリ }\end{array}$ & 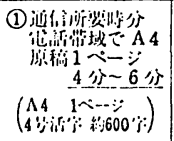 & 0 & 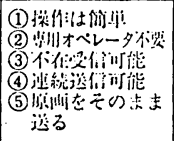 & 0 & 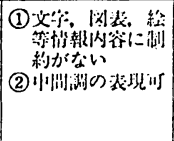 & 0 & 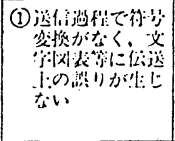 & 0 & 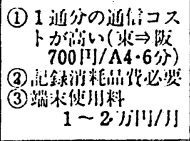 & $\times$ & $\mathrm{O}$ \\
\hline 种 优 & 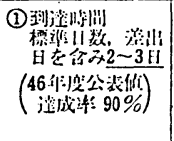 & $x$ & 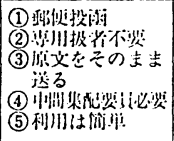 & $x$ & $\begin{array}{r}\text { (1)悄報队行の制約 } \\
\text { はまったくない }\end{array}$ & 0 & 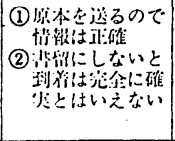 & 0 & 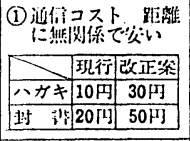 & 0 & $\Delta$ \\
\hline 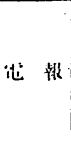 & 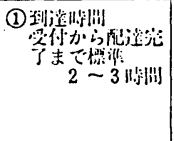 & $\Delta$ & 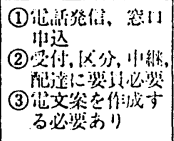 & $\Delta$ & 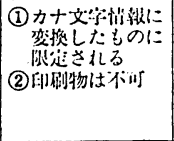 & $x$ & 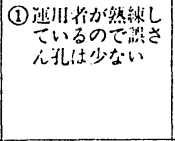 & $\Delta$ & 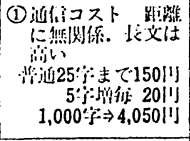 & $x$ & $\Delta$ \\
\hline $\begin{array}{l}\text { 加入 } \\
\text { 他保 }\end{array}$ & 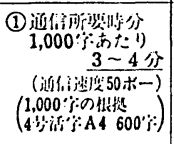 & 0 & 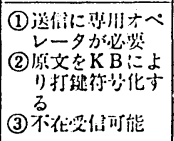 & $\Delta$ & 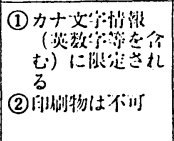 & $x$ & 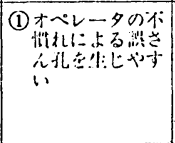 & $\triangle$ & 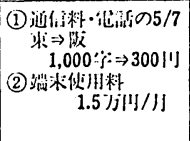 & 0 & $\Delta$ \\
\hline $\begin{array}{l}\text { 丁化き } \\
\text { 记送 }\end{array}$ & 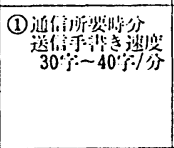 & 0 & 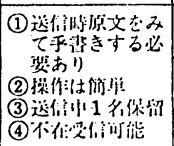 & 0 & 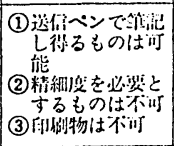 & $\Delta$ & 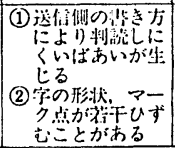 & o & 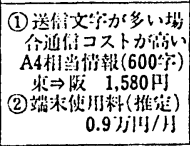 & $\Delta$ & 0 \\
\hline
\end{tabular}

つている。電送速度は 1 枚 3-4 分が一般的で, 1 分の もの更に 30 秒機器も一般市販されるよらになってきた。 線密度は $1 \mathrm{~mm}$ 当り 4 本前後である。大部分が送受兼用 で，自動受信，不在受信が可能であり，操作もいたって 簡単である。費用は買取り、レンタル,リース等いろい ろある。記録紙は 1 枚 18 円位である。画像品質がまだ 十分とはいえないが，フオマットを調整すれば一般の文 書の送受信には十分使えると思う。また，最近ではこの 種の端末機の開発は活発であるので, 今後低コストで, 便利なよい端末機が出てくるものと思われる。

\section{6. 将来の展望}

わが国に拈けるファクシミリの利用台数は電写研究会 と画像電子学会の調查によれば

昭和42年 9 月現在 1.7 万台 昭和 47 年 9 月現在 4.1 万台

で，年率約 $20 \%$ の成長を示している。又，一般事務 用 部門の利用が伸びてきているといわれる。今後は

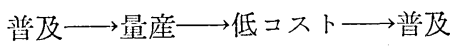

といった循環が期待できると思う。

図書館やその他の情報機関に和いても, 今後画像通信 システム, 特にフックシミリの覚入は大いに検討に值い すると思われる。利用方法としては一般事務用としての 要求伝票やその他一般文書類の授受の外, 画像品質の高
いものを採用すれば本や雑誌の特定のページを伝達する ことも可能であろう。雑誌論文の場合第 1 ページのみを 送れば，そこにはタイトル, 著者, サマリー,序論等があ るので，利用者はこれを読むことによって，早急に入手 ができるだけでなく，全論文のコピーを要求することが いくらかでも減少するであろら。さらに全国的ネットワ ークを組めば相互利用面での一層の活用がなされるであ ろら。

現在市販されている端末機は必ずしも利用者の要求を 満足させているとはいえない。しかし，先にも述べたよ らに今後はコストの面でも, 機能的にも要求に答えるも のが出るはずである。今後の情報社会において画像通信 のニードは将来に向って開けているものといえるだろら。 館界の皆さんがこれに注目されたのははなはだ喜ばしい ことである。

\section{参 考文 献}

窪田啓次郎 : 画像と情報の記録一端末機とそのハードコ ピー— 電子通信学会 1975.

小林 登: 画像電送システムの展望. ビジネス・コミュ ニケーショソ 12(7)：28-37,1975. その他この 号は“画像電送”システム特集号となっている。

(昭和 51 年 1 月 23 日受付)

医学図書館 22 巻 1 号 ('75) 